\title{
Pemberdayaan Masyarakat Melalui Pelatihan Pengolahan Sayuran Menjadi Selai Dengan Metode Atmospheric Sebagai Alternatif Usaha Keluarga Di Kelurahan Rajawali Jambi
}

\author{
Novita Sari ${ }^{1}$, Fitri Chairunnisa ${ }^{2}$, Rosmeli $^{3}$ \\ Fakultas Ekonomi dan Bisnis, Universitas Jambi, Indonesia
}

\section{PENDAHULUAN}

Kelurahan Rajawali adalah salah satu dari sembilan kelurahan yang ada di Kecamatan Jambi Timur, dengan luas wilayah 31.060 Ha dan jumlah penduduk sebanyak 8.441 jiwa. Dari total jumlah penduduk, sekitar $60 \%$ sudah memiliki mata pencaharian dengan berbagai tingkat penghasilan. Hanya $33 \%$ warga yang berusia diatas 15 tahun, dimana $17 \%$ masih berada di usia sekolah dan sisanya berada di usia produktif. Jumlah penduduk terbanyak di kelurahan ini adalah perempuan, yaitu sebanyak 4.304 jiwa atau $51 \%$ dari total penduduk yang ada, sedangkan jumlah penduduk laki - laki adalah sebanyak 4.107 jiwa atau $49 \%$ dengan jumlah KK sebanyak $2.061 \mathrm{KK}$.

Tingkat kesejahteraan masyarakat di kelurahan ini belum terlalu baik, karena untuk memperoleh pekerjaan dengan penghasilan yang bisa mencukupi kebutuhan keluarga dibutuhkan tingkat pendidikan yang tinggi ataupun memiliki ketrampilan tertentu. Sedangkan mayoritas penduduk di kelurahan Rajawali ini adalah tamatan SMA. Selain itu, sebagian besar ibu rumah tangga di kelurahan ini tidak bekerja, sehingga seringkali penghasilan yang diperoleh tidak mencukupi kebutuhan hidup.

Di kelurahan Rajawali terdapat beberapa Lembaga masyarakat da $\mathrm{n}$ salah satunya adalah Pusat Kegiatan Belajar Masyarakat (PKBM). Lembaga ini diketuai oleh ibu Tuti WH. PKBM ini terletak di RT 21 Kelurahan Rajawali dan menawarkan beberapa program sebagai berikut:

1) Pendidikan Keaksaraan

2) PAUD

3) Pendidikan Kesetaraan (Paket A, B dan C)

4) Bina Keluarga Balita (BKB)

5) Posyandu Melati 1

6) Pelatihan dan Kursus (Bimbel, menjahit dan komputer)

7) Peduli ASI

8) Kecakapan Hidup

9) Taman Bacaan Masyarakat

10) Karang Taruna dan Olahraga

11) Kelompok Belajar Usaha (Home industry : Raja dodol, Sablon Tiara, Cake and Catering Bunda, Catering Annisa)

PKBM ini adalah salah satu sarana pendidikan nonformal yang mendukung kehidupan berkelanjutan. Dalam menjalankan kegiatannya PKBM bekerja sama dengan banyak pihak seperti Dinas Pendidikan, Dinas Kesehatan, Dinas Sosial dan Ketenaga Kerjaan, Tim Penggerak PKK kelurahan ataupun swasta lainnya. Untuk itu, akan sangat baik apabila pihak eksternal bekerja sama dengan PKBM agar program-program yang ditawarkan bisa tetap berkelanjutan.

Yang menjadi hambatan terbesar dari PKBM ini adalah keterbatasan bahkan ketersediaan biaya, padahal program-program yang ditawarkan tersebut bertujuan untuk meningkatkan kualitas sumber daya manusia, generasi penerus bangsa dan juga para ibu rumah tangga, sebagai komponen potensial untuk menambah penghasilan keluarga. Untuk itulah, Tim 
akan melakukan kegiatan pelatihan kepada para ibu yang tergabung dalam Kelompok Belajar Usaha (KBU) yang berada dibawah naungan PKBM ini. Pelatihan yang diperoleh warga ini, diharapkan nantinya akan membangkitkan semangat berwirausaha dan menjadi modal untuk meningkatkan pendapatan keluarga di kelurahan Rajawali ini.

\section{Permasalahan Mitra}

Lapangan pekerjaan yang tersedia saat ini, tidak mampu menyerap tenaga kerja dalam jumlah yang besar. Ditambah lagi dengan tingkat Pendidikan ataupun ketrampilan yang tidak selalu sesuai dengan persyaratan pekerjaan yang ditawarkan, membuat semakin banyak warga usia produktif yang tidak memiliki pekerjaan. PKBM di kelurahan Rajawali ini adalah salah satu sarana pendidikan nonformal yang pendukung kehidupan berkelanjutan. Salah satu forum yang ada di bawah naungan PKBM ini adalah Kelompok Belajar Usaha (KBU), yang beranggotakan para ibu rumah tangga dan remaja putri yang ada di kelurahan Rajawali. Mereka adalah sumber daya manusia yang ingin berwirausaha untuk menambah penghasilan keluarga namun memiliki keterbatasan dalam ketrampilan yang dimiliki. Untuk itulah diperlukan pelatihan ketrampilan, yang nantinya bisa dimanfaatkan untuk mewujudkan kebutuhan dan keinginan mereka tersebut.

Hasil analisis situasi yang ada pada PKBM di kelurahan Rajawali ini khususnya pada Kelompok Belajar Usaha (KBU) adalah sebagai berikut:

1. Tingkat kesejahteraan anggota yang masih rendah

2. Tidak memiliki sumber keuangan yang cukup untuk menjalankan program

3. Keterbatasan ketrampilan yang dimiliki oleh para anggota

4. Minat berwirausaha terkendala keterbatasan para anggota

Dari kondisi tersebut maka perlu dilakukan suatu pelatihan. Selain untuk meningkatkan ketrampilan para anggotanya, juga untuk membangkitkan minat berwirausaha, sehingga mereka bisa membantu meningkatkan pendapatan keluarga.

\section{SOLUSI DAN TARGET DAN LUARAN}

\section{Solusi}

Melihat permasalahan yang terjadi pada mitra, maka kegiatan yang akan dijalankan dalam Program Pengabdian kepada Masyarakat ini disesuaikan dengan kondisi mitra dan potensi sumber daya manusia yang ada.

1. Melakukan pelatihan pengolahan sayuran yang mudah diperoleh dimana saja dan harganya sangat terjangkau, menjadi selai dengan metode atmospheric. Pelatihan ini akan langsung didemonstrasikan oleh chef / koki yang memang memiliki spesialisasi dalam pembuatan selai. Tujuan dari kegiatan ini adalah agar para peserta pengabdian benar-benar memahami tahapan pembuatan selai, mulai dari memilih bahan baku yang baik, pemilihan kandungan selai dan pengolahan yang higienis, sehingga menghasilkan selai berkualitas baik. Dan juga memberikan alternatif cara konsumsi bagi orang yang tidak menyukai sayuran.

2. Setelah tahapan pelatihan pembuatan selai selesai, kegiatan selanjutnya adalah memberikan pelatihan pengemasan (packaging). Kemasan yang akan digunakan tidak perlu mahal, namun harus mampu menjaga kualitas selai tetap baik dalam jangka waktu tertentu.

3. Yang tidak kalah pentingnya adalah pelaihan membuat label (labeling). Label tidak perlu menghabiskan banyak biaya. Namun label harus menarik dan menginformasikan kandungan selai yang dihasilkan nantinya. Label juga harus memberikan keterangan harga dan tanggal kadarluarsa. 
4. Kegiatan terakhir yang tidak kalah penting adalah pemasaran. Para anggota akan dibekali beberapa tips dan trik dalam memasarkan produknya. Baik secara offline maupun online. Dan apabila memungkinkan, PKBM akan mendaftarkan produk selai sayuran ini ke lembaga pengujian makanan (BPOM) dan juga mendapatkan sertifikat halal. Sehingga jangkauan pemasaran produk bisa lebih luas lagi.

Hasil akhir yang diharapkan dari kegiatan ini adalah selain mitra mampu menghasilkan selai sayuran dengan kualitas, packaging dan labeling yang baik, juga terjadinya peningkatan minat berwirausaha sehingga pelatihan yang telah diperoleh menjadi salah satu alternatif usaha peningkatan pendapatan keluarga.

\section{Target Luaran}

Rencana target luaran dari solusi-solusi yang diberikan kepada mitra melalui pengabdian ini adalah sebagai berikut:

Tabel 1. Rencana Target Capaian Luaran

\begin{tabular}{|c|l|c|}
\hline No & \multicolumn{1}{|c|}{ Jenis Luaran } & Indikator Pencapaian \\
\hline 1 & Publikasi ilmiah di jurnal/prosiding & Tidak ada \\
\hline 2 & Publikasi pada media masa (cetak/elektronik) & Ada \\
\hline 3 & $\begin{array}{l}\text { Peningkatan omzet pada mitra yang bergerak dalam } \\
\text { bidang ekonomi }\end{array}$ & Ada \\
\hline 4 & Peningkatan kuantitas dan kualitas produk & Ada \\
\hline 5 & Peningkatan pemahaman dan ketrampilan masyarakat \\
\hline 6 & $\begin{array}{l}\text { Peningkatan ketentraman/kesehatan masyarakat (mitra } \\
\text { masyarakat umum) }\end{array}$ & Ada \\
\hline 7 & Jasa, model, rekayasa sosial, sistem, produk/barang \\
\hline 8 & $\begin{array}{l}\text { Hak kekayaan intelektual (paten, paten sederhana, hak } \\
\text { industri, perlindungan varietas tanaman, perlindungan } \\
\text { topografi }\end{array}$ & Tidak ada \\
\hline 9 & Buku Ajar & Tidak ada \\
\hline
\end{tabular}

\section{METODE PELAKSANAAN}

Metode pelaksanaan kegiatan pengabdian ini menjelaskan tahapan mulai dari permasalahan yang dihadapi oleh mitra sampai dengan solusi yang ditawarkan untuk mengatasi permasalahan tersebut.

1. Pihak-pihak yang terlibat dalam kegiatan pengabdian ini yaitu dosen dan pemberi materi pelatihan (chef/koki).

2. Metode dan tahapan dalam kegiatan pengabdian ini adalah sebagai berikut: 


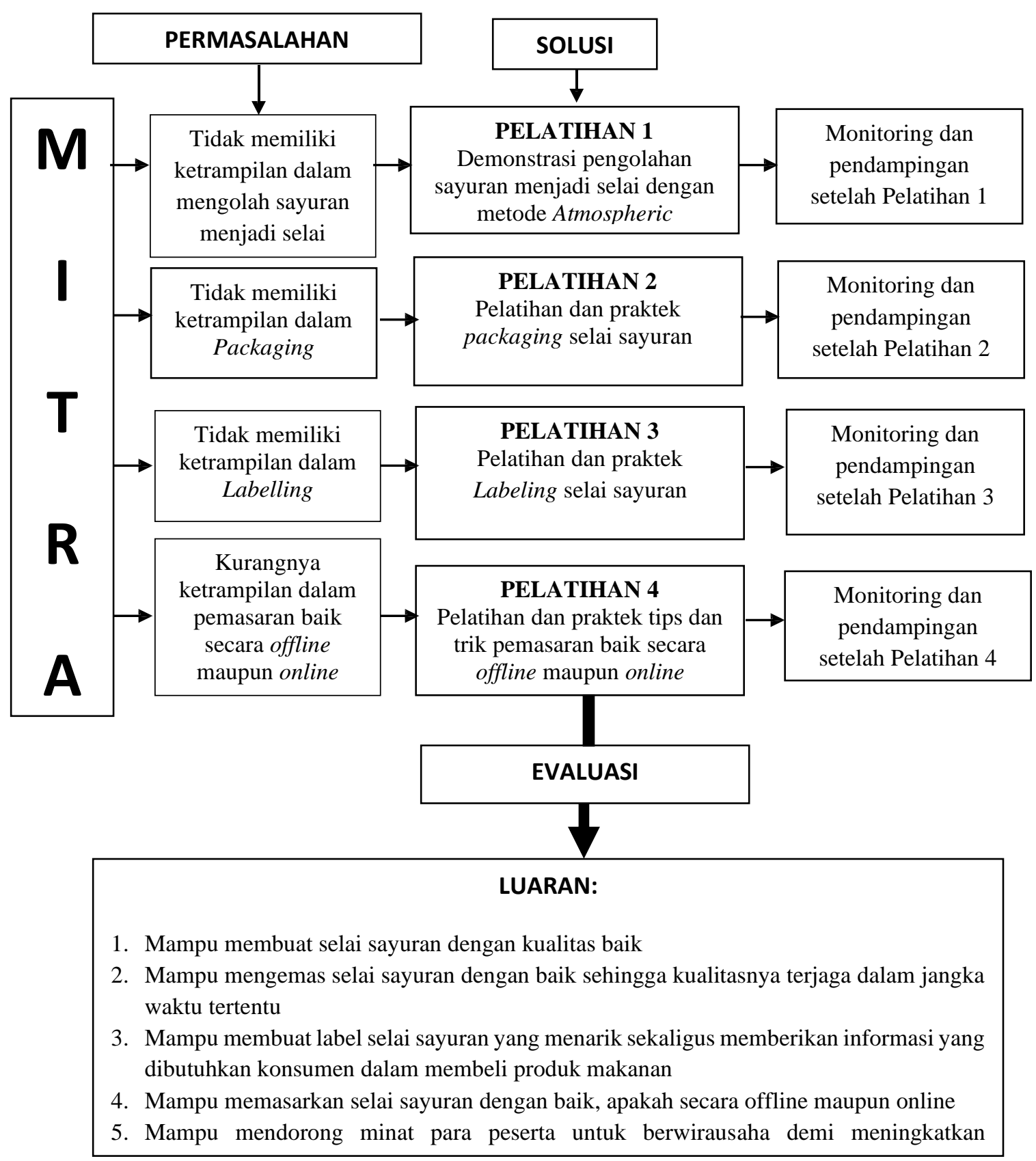

Kesimpulan dari kegiatan yang telah diuraikan diatas, maka pendekatan yang ditawarkan untuk menyelesaikan permasalahan mitra adalah sebagai berikut:

1. Metode Demonstrasi, Chef / koki akan menunjukkan secara langsung bagaimana tahapan pembuatan selai dari sayuran dengan metode atmospheric.

2. Metode Praktek, dimana para peserta bisa ikut serta untuk langsung mempraktekkan pengolahan sayuran menjadi selai dengan metode atmospheric.

3. Metode Ceramah dan Diskusi, disini para dosen akan memberikan materi yang berkaitan dengan packaging, labeling dan juga tips dan trik pemasaran produk selai sayuran tadi, baik secara offline maupun online. Kemudian para peserta diberikan kesempatan untuk mengajukan pertanyaan-pertanyaan yang berkaitan dengan materi yang diberikan. 


\section{HASIL PENGABDIAN}

\section{Demonstrasi Pengolahan Sayuran Menjadi Selai Dengan Metode Atmospheric}

Kelompok PKBM Rajawali yang dipimpin oleh ibu Tuti WH merupakan kelompok masyarakat yang terdiri dari para ibu rumah tangga, para pemuda dan masyarakat yang kurang mampu yang berada di Keluarahan Rajawali Kecamatan Jambi Timur Kota Jambi. Karena sebahagian besar anggota PKBM ini adalah para ibu rumah tangga dan tergolong pada keluarga kurang mampu, maka tim pengabdian pada masyarkat Fakultas Ekonomi Univeristas Jambi akan mencoba memberdayakannya melalui pelaksanaan pengabdian pada masyarakat dengan menggunakan bahan yang murah dan mudah didapat, cara yang mudah, penerapan system $3 \mathrm{R}$ (Reduse, Reuse \& Recycle) dan dapat dimanfaatkan untuk menambah penghasilan bagi para ibu berupa pelatihan pengolahan sayuran menjadi selai dengan metode Atmospheric.

Pelatihan dan demonstrasi ini melibatkan 25 orang ibu rumah tangga dengan 1 orang chef yang berasal dari salah satu hotel terkemuka di Kota Jambi. Untuk demonstrasi, sayuran yang digunakan adalah wortel dan sawi hijau. Pemilihan kedua sayuran ini dikarenakan kedua sayuran ini mudah didapatkan, murah harganya dan mengandung gizi yang tinggi serta enak untuk dijadikan selai sayuran.

Metode yang digunakan dalam pengolahan selai ini adalah metode atmospheric. Metode atmospheric adalah suatu metode pebuatan selai dengan menggunakan suhu ruang dan pengawet alami. Metode ini dipilih cukup mudah untuk diajarkan kepada orang awam.

Alat dan bahan yang digunakan dalam pengolahan sayur - sayuran menjadi selai adalah:

1. Sayuran (Wortel dan Sawi hijau)

2. Kompor

3. Kayu Manis

4. Gula

5. Garam

6. Lemon/Jeruk Nipis

7. Peralatan (Baskom, blender, pisau, spatula, dll)

Waktu yang dibutuhkan dalam pengolahan sayur - sayuran menjadi selai sayuran adalah sekitar satu jam (60 menit). Hal pertama yang dilakukan adalah mengupas wortel kemudian mencuci wortel dan diblender dengan menggunakan sedikit air. Setelah itu wortel dimasak menggunakan kompor dengan api sedang dengan terus diaduk perlahan. Kemudian ditambah sedikit air perasan jeruk nipis, gula dan sejumput garam. Selain sebagai pemanis, gula juga merupakan bahan pengawet alami. Setelah airnya menyusut, api dimatikan dan selai wortel telah siap untuk dikonsumsi. Hal yang sama juga dilakukan dalam pembuatan selai dari sawi hijau. Sawi hijau dipotong - potong dicuci dan diblender, lalu di masak dengan api kecil sambal terus diasuk. Tambahkan sedikit air perasan jeruk nipis, gula, sejumput garam dan kayu manis. Penambahan kayu manis berguna untuk menghilangkan bau yang sedikit menyengat pada sawi hijau. Setelah kering selai dari sawi hijau siap dikonsumsi. Untuk daya tahan, pada suhu ruangan selai wortel dan selai sawi hijau dapat bertahan selama 5 hari, Namun apabila disimpan dalam lemari pendingin, maka selai wortel dan sawi hijau dapat bertahan selama 3 bulan.

Dari hasil demostrasi yang telah dilakukan, para ibu - ibu yang mengikuti pelatihan merasa tertarik, karena selama ini mereka belum pernah membuat selai dari bahan baku sayuran. Selai yang selama ini dibuat hanya dari bahan baku buah - buahan seperti nanas.

\section{Pelatihan dan praktek Packaging dan Labeling}

Tujuan dari pengabdian pada masyarakat di PKBM Rajawali adalah menambah pengetahun dan keterampilan para ibu rumah tangga, dan menjadikan selai olahan dari sayuran ini menjadi 
salah satu sumber penghasilan tambahan bagi para ibu - ibu. Oleh karena itu adanya praktek packaging dan labeling untuk produk selai yang mereka buat.

Untuk packaging akan menggunakan toples selai daur ulang. Alasan pemilihan tempat selai daur ulang ini adalah:

1. Murah didapat

Diantara para ibu yang mengikuti pelatihan ini, ada beberapa orang ibu - ibu yang telah mengumpulkan toples kaca bekas selai yang telah kosong. Pemilihan tempat selai yang sudah tidak terpakai ini adalah karena mudah didapatkan dan tidak memerlukan biaya tambahan yang besar, sehingga harga dari packaging bisa lebih murah. Biaya yang dikeluarkan hanya biaya pembersihan tempat selai.

2. Ikut turut serta dalam 3R dan menyukseskan program pemerintah kota.

Salah satu program pemerintah kota yang sedang dijalankan saat ini adalah mengurangi sampah plastik terutama di pusat perbelanjaan. Tujuan akhir dari program ini adalah mengurangi penggunaan media plastik yang membutuhkan waktu sangat lama dalam proses penguraian di tanah. Hal ini menjadi salah satu pertimbangan bagi kami para tim pengabdian. Dengan menggunakan toples selai bekas, maka kita ikut serta dalam menyukseskan program 3R (Reuse, Reduse dan recycle).

Untuk labelling tim pengabdian pada mayarakat Universitas Jambi telah mendesain label produk yang sederhana, mudah diingat dan informatif. Dengan adanya packaging dan labeling maka, produk selai sayuran dari PKBM Rajawali telah dapat di komersialkan dan menjadi tambahan penghasilan bagi para anggota PKBM Rajawali. Penambahan izin dinkes dan penambahan label halal merupakan target kedepan, agar selai yang dihasilkan dapat masuk ke supermarket - supermarket yang ada di kota Jambi.

\section{Pemasaran Selai Sayuran PKBM Rajawali}

Untuk tahap awal, pemasaran selai akan dilakukan secara offline yaitu dengan menawarkan langsung produk kepada calon konsumen ataupun dengan menitipkan produk ke warung ataupun toko terdekat. Kemudian, pemasaran juga akan dilakukan secara online dengan system PO, melalui akun di Instagram ataupun Facebook. Kedepannya, diharapkan produk bisa mendapatkan label halal dan juga sertifikat BPOM, sehingga bisa dipasarkan ke supermarket yang ada di Kota Jambi, atau bila memungkinkan menjangkau wilayah yang lebih luas lagi.

\section{KESIMPULAN}

Berdasarkan hasil pengabdian kepada masyarakat, maka dapat diperoleh kesimpulan:

1. Selai wortel dan selai sawi hijau merupakan jenis selai yang dibuat dari sayur - sayuran segar dan tanpa bahan pengawet, sehingga memiliki keunggulan tersendiri.

2. Untuk menjadikan produk selai sayuran ini menjadi salah satu usaha yang mampu memberikan penghasilan tambahan dan mendukung program pemerintah untuk mengurangi sampah plastik, maka para anggota PKBM Rajawali dapat menggunakan toples bekas selai dengan menempelkan label produk yang telah didisain.

3. Penjualan selai sayuran secara bertahap dilakukan secara offline maupun secara online

\section{Saran} dengan system PO.

Dari kesimpulan yang telah diperoleh, maka saran yang dapat diberikan oleh tim pengabdian masyarakat Universitas Jambi adalah:

1. Peningkatan varian selai sayuran dengan menggunakan berbagai jenis sayuran yang lebih banyak lagi, sehingga menghasilkan produk yang lebih menjangkau berbagai segmen. 
2. Selain toples kaca bekas, produsen dapat menggunakan media penyimpanan lain yang layak pakai, sehingga dapat meminimalkan biaya produksi.

3. Mengusahakan produk selai sayuran rumahan ini untuk memperoleh sertifikat Halal dan BPOM, sehingga bisa menjangkau wilayah pemasaran yang lebih luas lagi.

\section{DAFTAR PUSTAKA}

Dutka, Alan, 2008. AMA Hand Book for Customer Satisfaction. NTC Business Book. Lincolnwood, Illinois

Kotler, Philip, 2003. Marketing Management. The Millenium Edition. Prentice-Hall International Inc. New Jersey.

Kotler dan Amstrong. 2004. Prinsip-prinsip Marketing, Edisi Ketujuh, Penerbit Salemba Empat, Jakarta. 